\title{
Tailles des perles et spécialisation artisanale
}

Enquête ethnoarchéologique dans le Gujarat

Valentine roux et Jacques Pelegrin

\section{(2) OpenEdition}

Journals

Édition électronique

URL : https://journals.openedition.org/tc/760

DOI : $10.4000 /$ tc. 760

ISSN : 1952-420X

Éditeur

Éditions de l'EHESS

\section{Édition imprimée}

Date de publication : 1 octobre 1990

ISSN : 0248-6016

\section{Référence électronique}

Valentine roux et Jacques Pelegrin, "Tailles des perles et spécialisation artisanale », Techniques \& Culture [En ligne], 14 | 1990, mis en ligne le 16 janvier 2006, consulté le 29 septembre 2022. URL: http://journals.openedition.org/tc/760 ; DOI : https://doi.org/10.4000/tc.760

Ce document a été généré automatiquement le 29 septembre 2022.

Tous droits réservés 


\section{Tailles des perles et spécialisation artisanale}

Enquête ethnoarchéologique dans le Gujarat

Valentine roux et Jacques Pelegrin 